\title{
OS PRINCÍPIOS ECONÔMICOS CONSTITUCIONAIS E A POSITIVAÇÃO PELA LEI DE FALÊNCIAS E RECUPERAÇÃO DAS EMPRESAS*
}

\section{THE ECONOMIC CONSTITUCIONAL PRINCIPALS AND THE POSITIVATION BY THE LAW OF BANKRUPTCIES AND RECOVERY OF THE COMPANIES}

Henrique Afonso Pipolo**

\begin{abstract}
Resumo: A partir da inserção dos princípios e valores em uma Constituição (no caso brasileiro a Constituição Federal de 1988), todas as normas constitucionais e infraconstitucionais produzidas na continuação do processo legislativo, devem ser por eles pautadas. No caso da Lei n. 11.101/05 denominada Lei de Falências e Recuperação das Empresas, tal orientação se observou, notadamente, diante dos seguintes princípios que norteiam a ordem econômica: propriedade privada, função social da propriedade e da empresa, livre concorrência, garantia do pleno emprego, suprimento das desigualdades regionais e sociais e tratamento diferenciado para as pequenas e micro empresas. $\mathrm{O}$ objetivo de preservar empresa economicamente viável está exposto por meio da referida lei possibilitando diante da realidade, efetivamente, vivenciar os efeitos do valor da função social que se irradia pela ordem jurídica brasileira, inclusive para o campo econômico-constitucional. Este processo de positivação constrói um novo panorama no mundo dos negócios, na gestão e políticas empresarias.
\end{abstract}

Palavras-chave: Recuperação e Manutenção de Empresas (Lei n. 11.101/ 05). Positivação dos Princípios Constitucionais Econômicos. Função Social. Falência.

Abstract: From the insertion of the principles and values in a Constitution, all the constitutional rules and infraconstitutional must be said by them. In the case of the Law of Bankruptcies and Recovery of the Companies (Law n. 11.101/05), such orientation has been observed accurately, in reason of the following principles that surrounds the Economical Order: private property, social activity of the property and the company, free

* Artigo extraído da Dissertação de Mestrado, apresentado ao Programa de PósGraduação Stricto Sensu da Universidade Estadual de Londrina, tendo como orientadora Prof ${ }^{\circ}$ Dro $^{\circ}$ Marlene Kempfer Bassoli.

**Mestre em Direito Negocial pela UEL na área de Processo Civil, Advogado, Professor. 
competition, guarantee of the full job, suppliment of the regional and social inequalities and differentiated treatment for small and micro companies. The main purpose of preserving the economically viable companies is exposed by such law enabling in reason of the reality, effectively, to see the effects of the value of the social activity that eradicates by the Brazilian Juridical Order, including for the economicalconstitucional field. This process of positivation builds a new panorama in the world of business in the management of business politics.

Keywords: Recovery and Maintenance of Companies (Law n.11.101/ 05). Positivation of the Economic Constitucional Principles. Social Activity. Bankruptcy.

\section{INTRODUÇÃO}

A Lei de Falências e Recuperação das Empresas (Lei n. 11.101/05) superou o antigo Decreto-Lei n. 7.661/45 e procurou adequar seu conteúdo e procedimentos ao Código Civil de 2002 (Lei n. 10.406/02), de modo a positivar os ditames da ordem econômica inserida na Constituição Federal de 1988.

A Teoria da Empresa, inserida no Código Civil, apresenta o empresário e a empresa como pedras angulares e o substrato para a interpretação das normas jurídicas reunidas no Direito Falimentar. De acordo com Arnold Wald (2003, p. 854), as alterações trazidas pelo Código Civil de 2002, em relação às empresas e empresários, não acarretaram apenas mudança na terminologia. Para o referido autor,

Não há dúvida de que, no particular, houve não só uma mudança de terminologia, mas uma substancial modernização das regras legais aplicadas às empresas e ao empresariado. Atendeu-se à evolução tecnológica, mas também à nova função atribuída à empresa, que passou a exercer importante função social.

Sendo assim, verifica-se que as normas jurídicas reunidas no Direito Falimentar têm-se pautado no sentido de possibilitar a manutenção no mercado de empresas que enfrentam dificuldades financeiras, mas ainda viáveis, tendo em vista a importância do seu papel e função social.

A modificação da Lei de Falências, tão almejada por credores, por empresários e pela sociedade, positivou os princípios constitucionais econômicos. Deve trazer boas perspectivas para a coletividade e para o trabalhador, pois a empresa, autorizada a permanecer em funcionamento, possibilita cumprir sua função social; cria condições de manutenção do emprego; preserva o exercício da livre concorrência, e proporciona um ambiente para o desenvolvimento regional. Além 
Os princípios econômicos constitucionais e a positivação pela lei de falências...

do tratamento diferenciado no procedimento da Recuperação para micro e pequenas empresas, também positiva, em relação à falência, o princípio constitucional da celeridade processual. Isso porque permite uma maior agilidade na realização dos ativos do falido, proporcionando pagamento mais rápido aos credores.

\section{A LEI FALIMENTAR E DE RECUPERAÇÃO DAS EMPRESAS}

O conjunto de dispositivos da Nova Lei de Falências (NLF) forma um todo de natureza mista, contando com normas de direito material e adjetivo. Apesar de levar o epíteto "Lei de Falências", como herança do Decreto-Lei n. 7.661/45, o objetivo da legislação atual é evitar, o quanto possível, a decretação da quebra. Para cumprir esse desiderato o novo texto apresenta várias alternativas judiciais e extrajudiciais de recuperação das empresas, em estado de insolvência iminente, com a participação direta dos credores, e sob a fiscalização do administrador judicial e do Poder Judiciário.

Inspirada no capítulo 11 da Lei de Falências dos Estados Unidos ${ }^{1}$, a nova Lei de Falências brasileira não diz respeito apenas às empresas em estado de insolvência. Repercute, também, diretamente sobre a administração das empresas saudáveis e em funcionamento e das pessoas que com ela se relacionam, como sócios, gestores, funcionários, fornecedores, clientes, investidores, parceiros, e principalmente o Estado.

Destaca-se a função social que hoje a atividade empresarial exerce, responsável pela geração de riquezas, criação de empregos e renda, contribuindo para o desenvolvimento econômico e social do país. Depois de esgotadas muitas possibilidades, a falência deve ser decretada. Assim, caberia epíteto melhor à nova legislação: "Lei de Recuperação Empresarial".

No Brasil, ressalta-se que a nova lei pautou-se pelos mesmos interesses e objetivos dos sistemas que são utilizados em outros países. Existem dois tipos de procedimentos para recuperar a empresa: um judicial, onde o devedor, cumpridos os requisitos legais, apresenta seu plano de recuperação em juízo e, após a aprovação pelos credores, o juiz concederá a recuperação judicial; e outro

${ }^{1}$ Os Estados Unidos da América regulam a recuperação da empresa no Capítulo 11 do Bankruptcy Code. A legislação permite que o devedor continue na administração da empresa, sendo possível uma negociação entre os credores e o devedor em dificuldades, de forma que a solução encontrada por eles será respeitada pelo Judiciário, sendo que este somente intervirá se houver desequilíbrio entre os diferentes credores. 
Henrique Afonso Pipolo

extrajudicial, onde o devedor apresenta o plano aos credores extrajudicialmente e, uma vez aceito, poderá ser apresentado em juízo para homologação.

\section{REGIME JURÍDICO POSITIVADO PARA LEI DE FALÊNCIAS E RECUPERAÇÃO DA EMPRESA}

A Lei n. 11.101/05 positiva o regime jurídico para os procedimentos da Falência e da Recuperação das empresas, apresentando princípios e regras específicas. Os princípios que fundamentam a Lei de Falência e Recuperação da Empresa estão voltados para a busca de soluções rápidas da crise e para a mantença da atividade empresarial. Quer-se viabilizar a tendência crescente do sistema legislativo e judiciário brasileiro de desburocratizar rotinas, simplificar e acelerar procedimentos, sem comprometer o formalismo necessário e inerente à juridicidade.

Para alcançar tais propósitos, referido regime jurídico das empresas em situação de falência ou recuperação é composto por vários princípios, dentre eles: o da preservação da empresa; da recuperação da empresa; da proteção aos trabalhadores; da celeridade e eficiência dos processos judiciais; da participação dos credores; e da valorização dos ativos do falido.

\section{RECUPERAÇÃO EMPRESARIAL}

A Lei n. 11.101/05 (Lei de Falência e Recuperação Empresarial - LFR) trouxe o instituto da recuperação (judicial ou extrajudicial) em substituição à antiga concordata. Objetivou o legislador, ao máximo, proteger o empresário de uma possível decretação de falência, pois criou mecanismos para que uma sociedade empresária ou firma individual possa superar uma crise econômicofinanceira que momentaneamente esteja passando.

Através do instituto da recuperação é possível manter em funcionamento a empresa devedora preservando a manutenção da fonte produtora, o emprego e o interesse dos credores. Isso porque a função social da empresa passou a ser tutelada pelo ordenamento jurídico pátrio de forma mais agressiva e evidente, adequando a situação pretérita de individualidade aos anseios sociais da atualidade.

Em tempos onde o Estado não é capaz de cumprir com todas as suas responsabilidades mínimas, tenta-se transferir, para o particular, um pouco dessas responsabilidades. Visualizando nas empresas uma fonte de produção de riquezas que pode contribuir, em muito, com o desenvolvimento social, sentiu o legislador a necessidade de proteger um pouco mais o empresário que, por motivos variados, passar por momentânea crise econômico-financeira. Destarte, criou mecanismos 
Os princípios econômicos constitucionais e a positivação pela lei de falências...

para que o empresário saia dessa situação de penúria vale dizer a recuperação judicial e extrajudicial.

O Art. 47 da LFR traz os objetivos da recuperação judicial: viabilizar a superação da situação de crise econômico-financeira do devedor; manutenção da fonte produtora, do emprego dos trabalhadores e dos interesses dos credores; promover a preservação da empresa, sua função social e o estímulo à atividade econômica.

A recuperação da empresa pressupõe um “acordo" com os credores. $\mathrm{Na}$ recuperação extrajudicial o devedor, conhecedor de suas dificuldades e preenchidos os requisitos legais (Art. 161 c/c 48 da LFR), convoca seus credores para que se manifestem sobre uma proposta (plano) de recuperação. Uma vez aceito o plano (mínimo de 3/5 dos credores de cada classe), o juiz homologará o plano para que surta seus efeitos.

$\mathrm{Na}$ recuperação judicial, uma vez cumpridos os requisitos legais (Art. $48 \mathrm{da}$ LFR), o juiz deferirá o processamento da recuperação, devendo o devedor apresentar, em 60 dias da publicação do deferimento (Art. 53 da LFR), o plano para recuperação. Não havendo impugnação de qualquer credor em 30 dias, o juiz concederá a recuperação (Art. 58 da LFR). Caso exista impugnação, o juiz convocará a assembléia de credores que deverá se manifestar sobre o plano apresentado. Aprovado o plano, o juiz concederá a recuperação e, caso contrário, decretará a falência do devedor (Art. 56, §4 $4^{\underline{a}}$ da LFR), salvo a exceção do Art.58, $\S 1^{\underline{a}}$ da LFR (onde o juiz, mesmo diante da rejeição do plano pela assembléia dos credores e se constatada a presença dos requisitos deste artigo, poderá conceder a recuperação).

É certo que nem todas as dívidas da empresa serão englobadas no plano de recuperação, como, por exemplo, os tributários. Cuida-se de grande oportunidade para que o empresário possa reorganizar e reordenar sua atividade e sua situação econômico-financeira e superar a crise instalada. Não há uma unanimidade na doutrina em relação ao modelo de recuperação apresentado na Lei atual. Fábio Ulhoa Coelho (2005, p. 116) entende que a recuperação das empresas deveria ser realizada no âmbito do próprio mercado inicialmente, sem qualquer intervenção do Estado (Poder Judiciário). Isso se daria através de investimentos a serem realizados por empreendedores ou investidores que vislumbrassem naquela empresa - em dificuldade - uma certa viabilidade na continuação de suas atividades. Se não houvesse tal interesse pelo próprio mercado, a saída seria a falência. Para ele,

[...] a recuperação da empresa não deve ser vista como um valor jurídico a ser buscado a qualquer custo. Pelo contrário, as más empresas devem falir para que as boas não se prejudiquem. Quando o aparato estatal é utilizado para garantir a permanência da 
Henrique Afonso Pipolo

empresas insolventes inviáveis, opera-se uma inversão inaceitável: o risco da atividade empresarial transfere-se do empresário para os seus credores.

Se as estruturas do livre mercado estão, em termos gerais, funcionando de modo adequado, as empresas em crise tendem a recuperar-se por iniciativa de empreendedores e investidores, que identificam nelas, apesar do estado crítico, uma alternativa de investimento atraente.

Referido autor afirma que, em algumas situações, o mercado não conseguiria recuperar a empresa não pelo fato de ser ela um péssimo investimento, mas porque não se chega a um acordo em relação ao preço que o investidor quer pagar e o preço que o empresário quer receber. Diante desta situação, Fábio Ulhoa Coelho (2005, p. 119) aceita a intervenção do Estado (Poder Judiciário), mas apenas para garantir o regular funcionamento das estruturas do livre mercado. A solução para o caso não seria atribuição do juiz, mas simplesmente deveria afastar os obstáculos para que o mercado possa atuar de forma regular.

Não se nega que a lei de recuperação das empresas e seus procedimentos possuem algumas imperfeições, merecendo algumas alterações. No entanto, um grande passo foi dado para que se mantenha em funcionamento a empresa que está passando por dificuldades econômico-financeiras, preservando-se o emprego e a força produtiva beneficiando a sociedade, o Estado e os próprios credores.

\section{DA FALÊNCIA: CONSIDERAÇÕES E OBJETIVOS ATUAIS}

Os objetivos atuais da atual lei de falência são diversos daqueles que norteavam o antigo Decreto-Lei n. 7.661/45. A mudança de rumos ocorreu por vários motivos. A importância da função social da empresa na sociedade contemporânea e a evolução do Direito Comercial (empresarial) brasileiro que tomou por base a Teoria da Empresa.

O Decreto-Lei apresentava, como principal objetivo da falência, a defesa dos interesses dos credores, predominando sobre qualquer outro. "Seu enfoque preferencialmente projetivo do crédito público e dos interesses dos credores insatisfeitos expunha um processo falimentar inconseqüente [...]” (FAZZIO JÚNIOR, 2005, p. 18). Tais fatores contribuíam para que o procedimento da falência tivesse sua natureza desvirtuada. Buscava-se mais a cobrança de um crédito do que propriamente a decretação de falência do devedor.

Os credores iniciavam um processo de falência contra o devedor para coagilo a pagar dívidas que estavam vencidas e ainda não liquidadas. A impontualidade injustificada do devedor, por qualquer valor, era um dos fundamentos que motivavam o início do procedimento falimentar e, em muitos casos, a decretação da falência. 
Os princípios econômicos constitucionais e a positivação pela lei de falências...

Uma vez ajuizada a ação falimentar, o devedor, na antiga lei, não tinha muitas alternativas para livrar-se daquela situação incômoda de ter, diante de si, a possibilidade da "quebra". Coagido pela situação, não restava outra saída ao devedor que objetivava continuar com seus negócios, senão depositar a quantia devida e elidir a decretação da falência.

A sistemática anterior dava condições para que uma empresa tivesse sua falência decretada por uma dívida de $\mathrm{R} \$ 1.000,00$ (um mil reais), por exemplo. Não havia qualquer fixação de valores mínimos para que a falência pudesse ser decretada. Isso fez com que o volume de ações ajuizadas dessa natureza atingisse patamares elevados.

Tal situação passou a incomodar os empresários, sendo que o Poder Judiciário, percebendo tal objetivo desvirtuado do credor (transformar a ação de falência em cobrança), começou a agir de forma a tentar, ao máximo, um acordo entre as partes para que a sentença de "quebra" não fosse proferida. Tentava-se, de toda a forma, a manutenção da empresa. Nem sempre o credor tinha sucesso na sua empreitada. Inúmeros foram os casos onde o credor ajuizou o pedido de falência objetivando apenas coagir o devedor a efetuar o pagamento do débito e foi surpreendido pelo não pagamento, tendo como conseqüência a falência decretada. Não poderia ser pior, pois a falência da sociedade empresária colocava, na grande maioria das vezes, uma pá de cal em qualquer possibilidade de o credor receber o crédito, seja total, seja parcial.

A Lei n. 11.101/05 mudou tal panorama. Restou estabelecido, no Art. 94, inciso I, um valor mínimo de crédito para que a falência possa ser decretada 2 . Somente créditos com valor superior a 40 (quarenta) salários mínimos na data do pedido de falência é que poderá ensejar a decretação da "quebra" do empresário.

Constata-se que a legislação procurou fazer com que o processo de falência somente fosse manejado por credores que fossem titulares de um crédito de valor relevante. $\mathrm{O}$ interesse do credor de receber um crédito inferior a 40 salários mínimos deve ser buscado através de processo de cobrança ou execução.

O volume de pedidos de falência ajuizados nos últimos meses caiu drasticamente $^{3}$. A partir do início de vigência da Lei n. 11.101/2005 que ocorreu

${ }^{2}$ Art. 94. Será decretada a falência do devedor que: I - sem relevante razão de direito, não paga, no vencimento, obrigação líquida materializada em título ou títulos executivos protestados cuja soma ultrapasse o equivalente a 40 (quarenta) salários mínimos na data do pedido de falência.

${ }^{3}$ Segundo estudos divulgados pelo SERASA, o volume de falências decretadas e falências requeridas apresentaram queda significativa em fevereiro. No mês foram decretadas 
em 09 de junho de 2005, a falência passou a ser um instrumento jurídico manejado de forma mais racional, de forma que deixou de ser um meio de coação para recebimento de pequenas quantias.

Não se maneja mais, atualmente, o processo de falência como meio de coagir o devedor a saldar a dívida, mas efetivamente liquidar a sociedade empresária ou a firma individual, de forma a valorizar os ativos do devedor para que os credores possam ver seus interesses satisfeitos.

O Art. 75 da LFR delimita os objetivos específicos e que devem ser perseguidos no procedimento da falência: "preservar e otimizar a utilização produtiva dos bens, ativos e recursos produtivos, inclusive os intangíveis, da empresa”. Para alcançar essa meta há autorização legal para o afastamento do devedor de suas atividades. A medida tem por finalidade preservar e otimizar a utilização dos bens da empresa, de forma que esta possa, inclusive, permanecer no mercado.

Confirma-se essa interpretação diante do regramento legal para realizar o ativo do devedor que traz, em primeiro lugar, a alienação da empresa, com a venda de seus estabelecimentos em bloco, a teor do Art. 140, I, da LFR ${ }^{4}$

Art. 140. A alienação dos bens será realizada de uma das seguintes formas, observada a seguinte ordem de preferência:

I - alienação da empresa, com a venda de seus estabelecimentos em bloco;

Segundo Waldo Fazzio Júnior (2005, p. 351), "realizar o ativo, em regra, consiste em converter os bens do devedor em dinheiro, para pagamento de seu passivo".

118 falências, um recuo de 43,5\% sobre o mesmo mês do ano anterior - conforme nota do Valor Online. Em fevereiro de 2005, foram 209 falências decretadas. Já as falências requeridas apresentaram queda de $62,6 \%$ no segundo mês do ano, comparado ao mesmo período de 2005 . Foram requeridas 317 falências contra 847 no ano passado. No bimestre, a queda nos requerimentos foi de 66,7\%. De 1.879 eventos registrados em 2005 passou-se para 626 em 2006. Notícia publicada no site <http:// pegntv.globo.com/Pegn/0,6993,VVP0-2659-224017,00.html>. Acesso em: 23 mar. 2006.

${ }^{4}$ Art. 140. A alienação dos bens será realizada de uma das seguintes formas, observada a seguinte ordem de preferência:

I - alienação da empresa, com a venda de seus estabelecimentos em bloco;

II - alienação da empresa, com a venda de suas filiais ou unidades produtivas isoladamente;

III - alienação em bloco dos bens que integram cada um dos estabelecimentos do devedor;

IV - alienação dos bens individualmente considerados. 
Os princípios econômicos constitucionais e a positivação pela lei de falências...

O rol apresentado pelo legislador para realização do ativo é meramente exemplificativo, pois o Art. $145^{5}$ da mesma Lei apresenta a possibilidade de outras formas de realização do ativo serem aceitas, desde que aprovadas pela assembléia geral de credores. Pode-se contemplar, como meio de realização do ativo, por exemplo, a formação de sociedade ou cooperativa dos funcionários ${ }^{6}$ do próprio devedor ou sociedade entre os credores para que possam adquirir a empresa.

Conclui-se que a alienação da empresa, no todo ou em parte, é a principal forma que a lei apresenta para realização do ativo do devedor. Somente se a empresa não vier a ser negociada é que os bens serão vendidos de forma individual. Demonstrado está que os meios de realização do ativo permitem à empresa continuar exercendo seu papel na sociedade. Daí a importância de não se confundir a empresa com a sociedade empresária. Esta é quem vai sofrer os efeitos da falência, pois ela é quem pode ser rotulada como o sujeito da atividade empresarial. A empresa, considerada como o objeto da sociedade empresária, pode desprenderse desta.

A própria lei apresenta mecanismos para que o adquirente da "empresa" não tenha qualquer vinculação com as obrigações da sociedade falida. Isso quer dizer que todas as obrigações do falido permanecem com a sociedade empresária ou empresário individual que sofreram o processo de falência. Não há qualquer sucessão de obrigações, a teor do Art. 141, II da LFR?

Ressalta-se que em algumas situações o dispositivo mencionado não se aplica. É o caso do próprio sócio da sociedade falida, ou sociedade controlada pelo falido adquirir a empresa. Nessa situação, ocorre a sucessão de obrigações. As exceções constam do Art. 141, § $1^{\underline{a}}$ da LFR.

${ }^{5}$ Art. 145. O juiz homologará qualquer outra modalidade de realização do ativo, desde que aprovada pela assembléia geral dos credores, inclusive com a constituição de sociedade de credores ou dos empregados do próprio devedor, com a participação, se necessária, dos atuais sócios ou terceiros.

${ }^{6}$ Aos funcionários, inclusive, é permitida a utilização dos seus créditos derivados da legislação do trabalho para a aquisição ou arrendamento da empresa, a teor do art. 145 , § $2^{\circ}$ da Lei de Falência.

${ }^{7}$ Art. 141. Na alienação conjunta ou separada de ativos, inclusive da empresa ou de suas filiais, promovida sob qualquer das modalidades de que trata este artigo:

I - $[\ldots]$

II - o objeto da alienação estará livre de qualquer ônus e não haverá sucessão do arrematante nas obrigações do devedor, inclusive as de natureza tributária, as derivadas da legislação do trabalho e as decorrentes de acidentes de trabalho. 
A inexistência de sucessão entre o empresário falido e a empresa, torna a aquisição desta mais atrativa ao mercado, pois eventuais investidores passam a ter uma situação definida em relação às suas obrigações, permitindo um investimento com menor risco.

Fábio Ulhoa Coelho (2005, p. 141-142) manifesta-se no sentido de que "se o adquirente da empresa anteriormente explorada pela falida tiver de honrar todas as dívidas dessa, é evidente que menos empresários terão interesse no negócio. Aliás, é provável que a própria alienação da empresa se inviabilize [...]”.

As possibilidades de uma venda por um preço considerável são maiores, sendo que, caso o negócio seja implementado, os credores terão evidentes benefícios, pois as chances de recebimento do que lhes é devido tornam-se mais concretas. Essa nova ordem traz no seu bojo a positivação de vários princípios do regime jurídico-constitucional econômico.

\section{O REGIME JURÍDICO ECONÔMICO-CONSTITUCIONAL E SUA POSITIVAÇÃO NA LEI DE FALÊNCIAS E RECUPERAÇÃO DE EMPRESAS}

O texto da Lei 11.101/05 traça alguns objetivos para os institutos da falência e da recuperação de empresas, que tornam possíveis a afirmação de que alguns princípios do regime jurídico econômico-constitucional estão sendo positivados pela referida lei. É o caso, por exemplo, da recuperação judicial, que tem por objetivo viabilizar a superação da situação de crise econômico-financeira do devedor. Quer-se manter a fonte produtora, o emprego dos trabalhadores e dos interesses dos credores, promovendo, assim, a preservação da empresa, sua função social e o estímulo à atividade econômica.

No que se refere ao instituto da falência, verifica-se que os objetivos elencados no texto da Lei 11.101/05, notadamente a possibilidade de alienação total da empresa por ofertas atrativas, de forma que o credor possa ter maiores possibilidades de receber aquilo que lhe é devido, confirmam a afirmação acima de que a nova Lei de Falências e Recuperação de Empresas está positivando certos princípios do regime jurídico econômico-constitucional, dentre os quais pode-se apontar a função social da empresa, livre concorrência, redução das desigualdades regionais e sociais, busca do pleno emprego e a celeridade processual.

\subsection{Recuperação da Empresa como Vetor de Desenvolvimento Econômico e Social}

A busca pela preservação da empresa estampada na Lei de Recuperação permite o desenvolvimento tanto econômico de uma sociedade, como também pode 
Os princípios econômicos constitucionais e a positivação pela lei de falências...

contribuir para a superação das desigualdades regionais e sociais. Se ao invés de recuperar-se, a empresa fechar suas portas ou até mesmo falir, vários serão os efeitos negativos. Isso porque há regiões que são mantidas por duas ou três empresas de grande porte, representando uma alta arrecadação de impostos e grande quantidade de empregos.

Se essas empresas forem acometidas por uma crise econômico-financeira há um grande risco de que toda a cadeia produtiva que é sustentada por elas seja atingida, acarretando uma desestabilização de graves conseqüências. "O princípio da redução das desigualdades regionais e sociais” encontra sua efetivação na lei de recuperação das empresas. A manutenção da empresa garante a circulação de riquezas, melhorando a vida da população que depende dela para sobrevivência.

\subsection{Positivação do Tratamento Especial para as Microempresas e Empresas de Pequeno Porte na Lei de Falências e Recuperação de Empresas}

A Constituição Federal de 1988 estabeleceu, em seu Art. 170, inciso IX e Art. 179 a obrigatoriedade de tratamento diferenciado (favorecido), por parte do Estado, em relação à microempresa e empresa de pequeno porte, de forma a criar condições para que tais empresas possam permanecer no mercado.

Fábio Nusdeo (1995, p. 205) defende o “princípio da preservação da empresa”. Para ele, "o princípio geral é o de não ser aceitável a norma cuja aplicação implique prejuízo para o grosso das empresas do setor ou para aquelas com estrutura de custos pelo menos não mais elevada do que a média”. E o grosso das empresas no Brasil é representado pelas micro e pequenas empresas.

Os benefícios dispensados à microempresa e à empresa de pequeno porte são de ordem creditícia, tributária, administrativa e previdenciária. Somando-se a tais benefícios, o legislador constituinte também determinou que a essas empresas fosse dado tratamento diferenciado na esfera judicial.

A Lei n. 11.101/2005 apresenta tratamento específico para o processamento da recuperação das microempresas e empresas de pequeno porte, positivando o quanto previsto nos Arts. 170 IX e 179 da Constituição Federal. Ressalta-se que somente as sociedades qualificadas como micro ou pequenas empresas é que poderão beneficiar-se do regramento diferenciado estabelecido nos Arts. 70 a 72 da LFR.

As vantagens são percebidas no processamento da recuperação da empresa, pois será muito mais simplificado. No procedimento das micro e pequenas empresas, ao contrário do que ocorre no procedimento das demais empresas, não há necessidade de deliberação em assembléia geral de credores acerca do plano especial formulado nos termos do Art. 72 e, uma vez cumpridas às formalidades pertinentes, o juiz concederá a recuperação. 
A Lei n. 11.101/05 não representou apenas vantagens para as referidas empresas quando positivou o aduzido princípio constitucional de proteção à empresa micro ou de pequeno porte. Isso porque os valores representados nos princípios econômico-constitucionais, muitas vezes, não são totalmente observados ou efetivados.

Em que pese o procedimento mais simples e célere apresentado, não permite que todas as dívidas do micro ou pequeno empresário sejam submetidas ao plano de recuperação. Somente os credores quirografários é que serão atingidos (Art. 71, I). Todos os outros créditos (trabalhistas, tributários, com garantias, etc) são mantidos da mesma forma, vale dizer, os credores continuam com o direito de cobrá-los de acordo com a lei.

De qualquer sorte, mesmo diante do quadro acima, não se pode negar que em casos onde o passivo da micro ou pequena empresa é representado, em sua maior parte, por dívidas quirografárias, o procedimento especial garantido pela Lei n. 11.101/2005 tem seus méritos.

\subsection{A Positivação da Função Social da Empresa Através da Realização do Ativo do Falido}

A Lei de Falência, ao permitir que a empresa seja adquirida como um todo por um investidor ou outro empresário para a realização do ativo do falido, coroou o princípio da "função social da empresa". Deixou de ser vista apenas como uma organização privada, que proporcionava benefícios apenas para poucos, para ultrapassar os muros dos interesses exclusivamente individuais, de forma a beneficiar toda a coletividade com uma vida digna, de acordo com os ditames da justiça social.

Sobre a função social da empresa, devem-se ressaltar os ensinamentos de Waldírio Bulgarelli (1985, p. 267-8):

É natural que, como centro polarizador da atividade econômica moderna já chamada de célula-mater da economia em nossos tempos, convergisse para a empresa uma variada gama de interesses, dizendo respeito aos trabalhadores, aos credores, ao Estado (quer na sua função mais mesquinha de arrecadador de impostos, quer como incentivador das atividades produtoras quer ainda como intérprete das aspirações populares ou do bem público), aos sócios ou acionistas em relação ao empresário coletivo; aos consumidores, à comunidade, etc.

É sem dúvida que a regulação ou a proteção desses interesses chega a extravasar a área delimitada do Direito Comercial indo a alcançar outros ramos do Direito. Era natural também que se acrescessem os deveres da empresa para com a sociedade e 
Os princípios econômicos constitucionais e a positivação pela lei de falências...

conseqüentemente a sua responsabilidade, ficando-se autorizado a conferir-lhe, por isso, uma função social conseqüente com a idéia natural de bem público.

A função social da empresa poderia ser considerada como certa limitação ao exercício dos direitos de propriedade, sendo que a aquisição em bloco da empresa faz com que o novo empresário, ao reorganizar os fatores de produção da empresa adquirida, o faça de forma, também, para atender aos interesses da coletividade. $\mathrm{O}$ valor da função social persegue a propriedade com quem quer que ela esteja.

\subsection{A Realização da Proteção do Emprego no Procedimento Falimentar}

O "princípio da busca do pleno emprego", constante do Art. 170, inciso VIII, da CF, também pode ser visualizado no texto falimentar. Ao manter-se uma empresa no mercado, mesmo tendo a sociedade empresária que a exercia falido, permite-se que a força de trabalho daquela atividade continue na ativa.

A idéia do "pleno emprego" foi conceituada com propriedade por José Afonso da Silva (1990, p. 667-8). Para ele,

Pleno emprego é expressão abrangente da utilização ao máximo grau de todos os recursos produtivos. Mas aparece, no art. 170, VIII, especialmente no sentido de propiciar trabalho a todos quantos estejam em condições de exercer uma atividade produtiva. Trata-se do pleno emprego da força de trabalho capaz.

Ao permitir que a empresa continue sua atividade, mediante a aquisição por outro empresário ou investidor, sem haver qualquer sucessão ou responsabilidade do novo empresário em relação às dívidas ou obrigações trabalhistas deixadas pelo falido, a norma jurídica vigente permite a recontratação do empregado. Cria-se uma oportunidade para que postos de trabalho sejam mantidos, mesmo diante da falência do empresário que dirigia aquela mão-de-obra.

Outro ponto da Lei de Falência que permite a manutenção do emprego é a realização do ativo pela formação de uma sociedade ou cooperativa dos trabalhadores da falida para adquirirem a empresa e continuarem com as atividades sociais. Essa possibilidade vai ao encontro do quanto estabelecido no Art. 174, § $2^{\circ}$ da Constituição Federal. Referido dispositivo estabelece que "a lei apoiará e estimulará o cooperativismo e outras formas de associativismo”. Para a consecução destes objetivos os funcionários podem utilizar-se de seus créditos derivados da legislação do trabalho para a aquisição ou arrendamento da empresa (Art. 145, § $2^{\circ}$ da LFR).

Buscou o legislador, portanto, uma das possíveis positivações do princípio do pleno emprego e do cooperativismo, de forma a proteger toda a classe trabalhadora que poderia ser dispensada e ficar na "fila do emprego" após a falência do devedor empresário. 
Henrique Afonso Pipolo

\subsection{A Manutenção da Empresa do Falido como Meio de Realização da Redução das Desigualdades Regionais e Sociais}

A busca pela redução das desigualdades regionais e sociais não pode ser tida apenas como um dos objetivos da República Federativa do Brasil (Art. 3aㅗ , inciso III), pois também baliza o desenvolvimento da atividade econômica (Art. 170, inciso VII). Para que se tenha um desenvolvimento econômico em determinadas regiões menos favorecidas, resta necessária a devida circulação de riquezas. Isto se dá de várias formas, sendo que o desenvolvimento, pela iniciativa privada, de atividade econômica organizada para a produção ou circulação de bens ou de serviços é a principal.

Sobre o princípio da redução das desigualdades regionais e sociais Américo Luis Martins da Silva (2003, p. 166), faz a seguinte observação:

Tratando-se de um sistema capitalista, parece-nos que a intenção do legislador constituinte brasileiro, ao elevar a redução das desigualdades sociais a princípio da ordem econômica, é de orientar a intervenção do Estado na economia no sentido de melhor distribuir a riqueza ou renda nacional, para se proporcionar um aumento no nível de vida, de consciência, de educação e de cultura das camadas inferiores da população, assegurando a cada membro o mínimo de que ele carece, individual e socialmente, para viver condignamente.

O empresário, ao exercer sua atividade, atinge toda a cadeia produtiva, de forma que os fornecedores de matéria-prima, materiais de mero expediente, marketing, etc, dependem dessa atividade para também manterem seus negócios e, a cada dia, ser expandido. Isto faz com que a circulação de riquezas ocorra. Ademais, ao manter a força de trabalho empregada, o empresário mantém consumidores em potencial, sendo que todo o comércio daquela região também será beneficiado.

Com a possibilidade de a empresa permanecer no mercado, mesmo após a falência, mas agora sob nova administração, cria-se o ambiente perfeito para o desenvolvimento econômico e social da região onde o empresário que irá exercer a empresa esteja instalado. Mais uma vez prova-se a relevância do quanto disposto na lei falimentar sobre a aquisição da empresa como um todo, desvinculando-a da sociedade empresária ou do empresário falido que a exercia.

\subsection{A Manutenção da Empresa como Forma de Preservação da Livre Concorrência}

A livre concorrência, princípio que orienta não apenas a ordem econômica constitucional brasileira (Art. 170, inciso IV), mas também o ideal capitalista pode ser visualizado na Lei de Falência. 
Os princípios econômicos constitucionais e a positivação pela lei de falências...

Por meio das regras que compõem a livre concorrência busca-se dar acesso e garantir a todos permanência no mercado. Tratando deste tema Tércio Sampaio Ferraz Júnior, citado por Eros Roberto Grau (2005, p. 210) afirma que "de um ponto de vista político, a livre concorrência é garantia de oportunidades iguais a todos os agentes, ou seja, é uma forma de desconcentração do poder”. Traduz a idéia de competitividade.

A Lei de Falência, ao permitir a preservação da empresa quando da realização do ativo, possibilitou que a atividade desenvolvida para a produção ou circulação de um tipo de bem ou um serviço específico fosse preservada, de forma a fomentar a concorrência entre os vários empresários do mesmo ramo.

Ao adquirir a empresa, o arrematante tem condições de novamente inseri-la no mercado, fazendo com que ela seja mais um elemento a participar da guerra saudável entre os segmentos da mesma natureza na busca por novos mercados consumidores ou, até mesmo, aumentar o número de consumidores que já possui.

Comprova-se que o princípio da livre concorrência a até mesmo a proteção dos direitos do consumidor foram contemplados na Lei de Falência, mesmo que de forma não tão explícita.

\section{DA CELERIDADE E EFETIVIDADE PROCESSUAL E O PROCEDIMENTO DA FALÊNCIA}

O processo civil, na sua atual fase de instrumentalidade, deve ser visto como um meio de se atingir os objetivos políticos, jurídicos, econômicos e sociais que a sociedade reclama. Cândido Rangel Dinamarco (2004, p. 257) afirma que "tal é o momento atual da ciência do processo civil-fase instrumentalista ou teleológica - em que se tem por indispensável definir os objetivos com os quais o Estado exerce a jurisdição, como premissa necessária ao estabelecimento de técnicas adequadas e convenientes".

A sociedade, já exausta de tantas vezes buscar o reconhecimento de um direito seu através de um processo lento, burocrático, ineficiente, muitas vezes, e extremamente caro, clama por soluções imediatas. Segundo Olavo de Oliveira Neto (2000, p. 100-1),

[...] nas últimas décadas aconteceu uma verdadeira revolução nos costumes e forma de organização social. A evolução das sociedades de massa levou um grande número de indivíduos a postular melhores condições de vida e, com esse anseio de uma sociedade mais igualitária e harmoniosa, veio também o anseio de se obter do Estado uma prestação jurisdicional eficiente. [...] Não bastava, todavia, a elaboração de novas leis, ampliando a possibilidade de defesa de direitos afirmados violados, se o sistema continuava, e continua moroso e ineficaz. Mister se fez, então, uma tomada de posição 
no tocante à agilização de todo o sistema processual, que desabrochou no tema "efetividade do processo", hoje tão discutido e prestigiado.

O processo civil tomou novos rumos, sendo que a efetividade e celeridade da prestação jurisdicional passaram a ter uma conotação de princípios, sendo inclusive elevados à condição constitucional. A Emenda Constitucional nª ${ }^{\mathrm{a}}$ 45, de 30 de dezembro de 2004, instituiu no Art. 5ª da Constituição Federal, o inciso LXXVIII, e estabeleceu que "a todos, no âmbito judicial e administrativo, são assegurados a razoável duração do processo e os meios que garantam a celeridade de sua tramitação”. Por razoável, deve-se entender um processo, conforme afirma Paulo Hoffman (2006, p. 41), "sem dilações ou atos desnecessários, realizados da forma mais rápida e eficaz e se e quando indispensáveis”.

Ainda, na visão de Hoffman (2006, p. 41),

não se pode, à custa de um processo mais célere, afrontar as garantias do devido processo legal nem gerar insegurança para as partes, tampouco forçá-las a comporse contra a vontade. Tanto é inaceitável um processo extremamente demorado côo aquele injustificavelmente rápido e precipitado, no qual não há tempo hábil para produção de provas e alegações das partes, com total cerceamento de defesa.

Há entendimentos de que o princípio da celeridade e o da economia processual derivam do princípio superior do acesso à justiça. Rita Dias Nolasco (2004, p. 34) entende que "[...] o princípio do acesso à justiça é o centro, do qual irradiam a assistência judiciária, o aumento dos poderes e deveres do juiz, a celeridade e efetividade do processo, etc".

A reformulação do Decreto-Lei n. 7661/45 deveria contemplar um processo falimentar e de recuperação que atingisse os anseios da coletividade, notadamente dos credores, de se ter um procedimento mais célere, efetivo e menos custoso. Veio a Lei n. 11.101/05 contemplar, no Parágrafo único do Art. 75, o princípio da celeridade e economia processual. Referido dispositivo estabelece que "o processo de falência atenda aos princípios da celeridade e da economia processual”. A Lei de Falência apresenta dispositivos que podem acarretar certa celeridade processual. É o que ocorre com os prazos, que são contínuos e peremptórios, não sofrendo suspensão em feriados, finais de semana ou férias forenses.

O Ministério Público não terá participação obrigatória em todos os feitos, pois o Art. 4⿳亠丷a da Lei n. 11.101/05 que previa tal intervenção foi vetado pelo Presidente da República. Tal fato acarreta considerável agilidade no procedimento falimentar. Também, o fato de a lei estabelecer a possibilidade de uma empresa especializada atuar como administradora judicial (figura do antigo síndico) poderá acarretar uma maior celeridade na prática dos atos processuais. Isso porque, na 
Os princípios econômicos constitucionais e a positivação pela lei de falências...

grande maioria das vezes, o síndico nomeado no procedimento do antigo DecretoLei n. 7661/45 não tinha grandes habilidades técnicas para desenvolver seu trabalho, acarretando maior demora na realização dos atos processuais.

Outra inovação que pode contribuir com a celeridade no procedimento da falência está na realização do ativo. Permite-se a venda dos bens mesmo que o quadro de credores não esteja completo, de forma a tornar o procedimento mais ágil, causando menos prejuízo aos credores, a teor do Art. 140, $\S 2^{\underline{a}}$.

Em relação aos créditos trabalhistas, o Art. 151 da Lei autoriza que os créditos trabalhistas de natureza estritamente salarial vencidos nos últimos três meses anteriores à decretação da falência, devam ser pagos a cada trabalhador, até o limite de cinco salários mínimos para cada um, tão logo exista dinheiro em caixa. Isso possibilita que esses credores não tenham que esperar a realização total do ativo para receber o mínimo para sua mantença, dando maior agilidade ao recebimento das verbas referidas.

Quanto à apuração dos crimes falimentares, constata-se que não há mais o inquérito em apenso aos autos de falência para apuração do delito. O Ministério Público, verificando a ocorrência de qualquer crime falimentar, promoverá imediatamente a competente ação penal ou, se entender necessário, requisitará a abertura de inquérito policial, sendo competente o juiz criminal da jurisdição onde tenha sido decretada a falência, a teor dos Arts. 183 e 187 da Lei n. 11.101/05.

Apesar das inovações, à primeira vista tem-se a impressão de que o procedimento tornou-se mais célere. Da leitura mais atenta do texto, no entanto, não se constata a agilidade desejada. Os procedimentos da atual da falência, principalmente em relação à primeira fase, que vai até a sentença que decreta a falência, ainda acarreta uma demora processual significativa. Isso por conta dos outros princípios que orientam o processo civil brasileiro, como o contraditório e ampla defesa. A matéria de defesa que pode ser discutida pelo devedor (art. 96, incisos de I a VIII), por exemplo, ampliou-se em relação ao procedimento anterior, sendo que tal fato contribui para uma demora maior no processo.

Outro ponto a ser destacado é o fato de que não há procedimento minucioso para a falência, sendo que a maioria dos dispositivos do Código de Processo Civil é utilizada de forma subsidiária, ante o regramento mínimo da Lei de Falências.

Ao comentar o procedimento da falência trazido pela Lei n. 11.101/05, Waldo Fazzio Júnior (2005, p. 244) afirma que:

[...] toda a matéria relativa à prova de defesa do devedor é regulada mediante a aplicação supletiva do estatuto instrumental civil, o que significa observar todas as normas pertinentes à instrução probatória (documentos, testemunhas, vistorias, exames, etc) do processo ordinário. $\mathrm{Na}$ prática, os pedidos de falência com arrimo na impontualidade e nos atos enumerados em lei poderão arrastar-se por longo 
tempo, na medida em que não se pode privar o devedor de realizar as provas necessárias à demonstração de suas razões para não pagar.

Mesmo diante da inserção na Lei de Falência do princípio da celeridade e economia processual e das mudanças apresentadas, na prática não se vislumbra, pelo menos neste momento, consideráveis mudanças no que se refere à agilidade de tramitação em relação ao antigo Decreto. Poderia o legislador ter previsto, ao menos, prazos específicos para o término do processo de falência.

É certo que as normas que disciplinam a falência estão no ordenamento jurídico há pouco tempo, sendo que não há uma estatística real para avaliar, de forma concreta, o quanto o procedimento falimentar melhorou. Mesmo diante de alguma melhora, perdeu-se uma excelente oportunidade para realmente dar uma sistemática eficaz e rápida aos processos falimentares, ou seja, um verdadeiro processo sumário.

\section{CONCLUSÃO}

Diante do estudo apresentado pode-se sublinhar:

1. O conteúdo econômico da Constituição brasileira de 1988 compõe um subsistema, que se caracteriza como um regime jurídico-constitucional econômico. Indica valores e princípios elencados, principalmente, no Art. 170 e incisos. Para esta pesquisa destaque-se a função social da propriedade privada e da empresa, da busca do pleno emprego, tratamento favorecido a empresas de pequeno porte e microempresas, livre concorrência, tudo a consagrar a finalidade da ordem econômica de assegurar existência digna, de acordo com os ditames da justiça social. Somando-se aos princípios citados tem-se o da celeridade processual, consagrado no Art. $5^{\circ}$, inciso LXXVIII, da CF.

2. O Estado, por meio dos Órgãos Legislativo (elaborando as normas abstratas e gerais inaugurais), Executivo (regulamentando e fiscalizando) e Judiciário (aplicando as leis ao caso concreto, de forma a resolver o conflito intersubjetivo), deve positivar os valores e princípios constitucionais econômicos. E assim o fez ao aprovar a Lei n. 11.101/2005 denominada de Lei de Recuperação das Empresas e Falência.

3. O Direito Comercial, que antes era fundado na Teoria dos atos de comércio, sofreu profundas transformações, principalmente na área empresarial. Passou a ser orientado por novos fundamentos denominados de Teoria da Empresa, cujo modelo inicialmente idealizado na Itália e que deixou de ter o comerciante e os atos de comércio como elementos centrais, passando o empresário e a empresa a nortearem todas as relações empresariais. 
Os princípios econômicos constitucionais e a positivação pela lei de falências...

4. Influenciado por novos pressupostos o Código Civil Brasileiro de 2002, ao adotar a Teoria da Empresa, revogou toda a parte geral do Código Comercial Brasileiro. Também orientou a elaboração da atual Lei de Falências e Recuperação das Empresas indicando que somente o empresário pode ser sujeito de recuperação ou falência nos moldes legais.

5. Inovou-se, também, na ordem jurídica brasileira, pois é a primeira vez que se busca manter a empresa em atividade, em evidente benefício da coletividade. È a positivação dos valores da função social da propriedade e da empresa, de forma a preservar o emprego e o desenvolvimento regional e social do local onde a empresa estiver instalada.

6. Mesmo tendo a Lei 11.101/05 garantindo tratamento diferenciado no procedimento da Recuperação das micro ou pequenas empresas, positivando o princípio esculpido no art. 170, inciso IX da CF, críticas são tecidas, pois abrangeu o referido plano de recuperação apenas os créditos quirografários, não contemplando os tributários, trabalhistas, previdenciários e com garantias reais. Ao deixar de fora tais créditos, podese inviabilizar a recuperação da empresa em dificuldade.

7. A atual Lei de Falência propicia a manutenção da empresa por meio da realização do ativo do devedor com a possibilidade da venda de seus estabelecimentos em bloco (Art. 140, I). A alienação com isenção de responsabilidades do adquirente em relação às dívidas da sociedade empresária falida é um dos atrativos mercadológicos.

8. A Lei de Falência, ao contemplar como forma de realização do ativo do falido a venda da empresa como um todo (Art. 140, I), permite que a atividade desenvolvida pela empresa continue. Possibilita-se, dessa forma, a convivência de aspectos dos princípios constitucionais da busca do pleno emprego, da livre concorrência e da redução das desigualdades regionais e sociais.

9. A busca pela celeridade processual fez com que o procedimento da falência fosse alterado. A não intervenção do Ministério Público em todos os processos; o processamento de eventuais crimes falimentares em autos específicos, no juízo criminal competente, extirpando-se definitivamente o inquérito judicial que era obrigatório no Decreto-Lei revogado; a realização do ativo do falido sob a forma de alienação global da empresa fundamenta uma agilidade processual.

10. Mesmo considerando alguns avanços em relação à celeridade do procedimento da falência, constata-se que na prática tal rapidez não se verificará. A inserção do princípio da celeridade processual, no parágrafo único do Art. 75 da Lei n. 11.101/05, não acarretará uma efetiva rapidez processual, ante as possibilidades de matérias a serem lançadas pelo devedor 
em sede de contestação. Toda a matéria probatória deverá obedecer aos trâmites do Código de Processo Civil, diante da falta de especificidade do texto falimentar. Somando-se a isto, não há qualquer prazo legal para que o processo de falência seja encerrado.

11. Poderia o legislador infraconstitucional, ante a oportunidade de modificar toda a sistemática processual do procedimento falimentar com a elaboração da nova lei falimentar, ser extremamente tímido, pois teria apresentado um procedimento sumário, com a efetiva concretização do princípio constitucional da celeridade processual, hoje previsto no art. $5^{\circ}$, inciso LXXVIII da CF.

\section{REFERÊNCIAS}

BULGARELLI, Waldirio. A teoria jurídica da empresa: análise jurídica da empresarialidade. São Paulo: RT, 1985.

COELHO, Fábio Ulhoa. Comentários à nova Lei de Falências e de recuperação de empresas. 3. ed. São Paulo: Saraiva 2005.

DINAMARCO, Candido Rangel. Instituições de direito processual civil. 4. ed. São Paulo: Malheiros, 2004. v. 1.

FAZZIO JÚNIOR, Waldo. Nova lei de falência e recuperação de empresas. 2. ed. São Paulo: Atlas, 2005.

GRAU, Eros Roberto. A ordem econômica na constituição de 1988 (interpretação e crítica). 10. ed. São Paulo: Malheiros, 2005.

HOFFMAN, Paulo. Razoável duração do processo. São Paulo: Quartier Latin, 2006.

NOLASCO, Rita Dias. Exceção de pré-executividade. 2. ed. São Paulo: Método, 2004.

NUSDEO, Fábio. Fundamentos para uma codificação do direito econômico. São Paulo: Revista dos Tribunais, 1995.

OLIVEIRA NETO, Olavo de. A defesa do executado e dos terceiros na execução forçada. São Paulo: Revista dos Tribunais, 2000.

SILVA, Américo Luis Martins da. A ordem constitucional econômica. 2. ed. Rio de Janeiro: Forense, 2003.

SILVA, José Afonso da. Curso de Direito Constitucional Positivo. 6. ed. São Paulo: Revista dos Tribunais, 1990.

WALD, Arnoldo. O empresário, a empresa e o Código Civil. In: MARTINS FILHO, Ives Gandra da Silva; MENDES, Gilmar Ferreira; FRANCIULLI NETTO, Domingos (Coord.). O novo Código Civil: estudos em homenagem ao professor Miguel Reale. São Paulo: Ltr, 2003. 